\title{
Immigrant Youth in Canadian Postsecondary Education: Pathway Morphologies in the Province of Quebec
}

Immigration et morphologie des parcours scolaires dans l'enseignement supérieur au Canada: le cas de la province de Québec Inmigración y morfología de las trayectorias académicas en la educación superior en Canadá: el caso de la provincia de Quebec

Pierre-Canisius Kamanzi, Marie-Odile Magnan, Annie Pilote and Pierre Doray

\section{OpenEdition}

Electronic version

URL: https://journals.openedition.org/remi/12100

DOI: $10.4000 /$ remi. 12100

ISSN: $1777-5418$

\section{Translation(s):}

Roma and Gypsies in the Mediterranean: Circulating Categories, Maintaining Boundaries - URL : https://journals.openedition.org/remi/8478 [en]

The Arab Spring: A Revolution for Egyptian Emigration? - URL : https://journals.openedition.org/remi/ 8481 [en]

"The cinema needs the individual, and migrants need the cinema to re-emerge as an individual." Interview with Andrea Segre - URL : https://journals.openedition.org/remi/8595 [en]

Mapping the Migratory Movements - URL : https://journals.openedition.org/remi/8803 [en] Immigration et morphologie des parcours scolaires dans l'enseignement supérieur au Canada : le cas de la province de Québec - URL : https://journals.openedition.org/remi/11280 [fr]

The measure of migratory flows between France and other countries; what if we also spoke of emigration? - URL : https://journals.openedition.org/remi/12090 [en]

Publisher

Université de Poitiers

Printed version

Date of publication: 1 October 2018

ISBN: 979-10-90426-62-7

ISSN: 0765-0752

\section{Electronic reference}

Pierre-Canisius Kamanzi, Marie-Odile Magnan, Annie Pilote and Pierre Doray, "Immigrant Youth in Canadian Postsecondary Education: Pathway Morphologies in the Province of Quebec ", Revue européenne des migrations internationales [Online], vol. 34 - n² et 3 | 2018, Online since 01 January 2021, connection on 14 April 2022. URL: http://journals.openedition.org/remi/12100 ; DOI: https:// doi.org/10.4000/remi. 12100 
This text was automatically generated on 14 April 2022.

(C) Université de Poitiers 


\title{
Immigrant Youth in Canadian Postsecondary Education: Pathway Morphologies in the Province of Quebec
}

\author{
Immigration et morphologie des parcours scolaires dans l'enseignement \\ supérieur au Canada: le cas de la province de Québec \\ Inmigración y morfología de las trayectorias académicas en la educación \\ superior en Canadá: el caso de la provincia de Quebec
}

Pierre-Canisius Kamanzi, Marie-Odile Magnan, Annie Pilote and Pierre

Doray

In recent decades, industrialized countries have been the destination of large waves of immigration (OECD, 2015, 2017). According to the latest OECD report (2017), approximately 124 million people residing in member countries of this organization were born abroad, representing about $13 \%$ of the total population, compared to $9.5 \%$ in 2000. The same report indicates that after the United States, Germany and the United Kingdom, Canada is the country that received the most immigrants during the 2004-2015 period, averaging 250,000 people each year. For example, in 2015, the country documented 272,000 new permanent residents. Among all countries, Canada and Australia have the largest proportion of immigrants (Ferrer, Picot, and Ridell, 2014). In 2016, the Canadian immigrant ${ }^{1}$ population was $7,540,830$, or $22 \%$ of the total population $(35,151,728)$ (Statistics Canada, 2017). While immigrants were dispersed across the country, the majority resided in three provinces: 3,852,145 (51\%) in Ontario, 1,292,675 (17\%) in British Columbia and 1,091,310 (15\%) in Quebec. In other words, these three provinces alone accounted for $6,236,130$, or $83 \%$ of the immigrant population. In addition, within these three provinces, almost one-third (27.4\%) of immigrants resided in the country's three major cities: 1,266,005 (17\%) in Toronto, 
Ontario; 570,940 (7\%) in Montreal, Quebec; and 262,765 (3.4\%) in Vancouver, British Columbia.

2 Canadian immigrants fall into three main categories: economic immigrants (skilled workers, investors), refugees, and those who arrive through family reunification (Statistics Canada, 2017). Compared to other OECD members, for several decades Canada has considered immigration mainly as a means of meeting the need for skilled labour (Ferrer et al., 2014). As such, the "economic immigrant" category represents roughly $60 \%$ of all immigrants (Martel and D'Aoust, 2016). Although this category also includes selected investors in accordance with the volume of funds they are prepared to invest, it mainly consists of future workers who are selected on the basis of different professional skill criteria, namely, level of education and qualification, knowledge of English or French, age, and professional experience. Nonetheless, regardless of the category to which they belong, newcomers are perceived as potential human capital that must be made profitable in the short or long term (Ferrer et al., 2014). According to economists, the sooner they are integrated into the structures of society, the better they are able to update their human capital and participate in economic activity (Djajic, 2003), which essentially encompasses the Canadian immigration policies' perspective (Ferrer et al., 2014).

3 The intensification of migratory movement in industrialized countries is characterized not only by an increase in the number of immigrants, but also by the diversity of their origins. In the past, immigration generally occurred between industrialized countries themselves, most often between neighbouring and bordering states. However, since the end of the last century, migratory flows have diversified and expanded to southern countries (Zlotnik, 1991, 1995), particularly in Asia (OECD, 2017). Throughout Canada, about $60 \%$ of immigrants are from Asia, 17\% from Africa, and 12\% from Europe (Martel and d'Aoust, 2016). However, the situation varies among provinces. Thus, compared to the rest of Canada, Quebec (the only French-speaking province) receives fewer immigrants from Asia than from Africa, among which those from North Africa are the largest group. This difference is largely explained by the provisions of the Canadian constitution since the 1960s, which provide for the sharing of immigration powers between the federal and provincial governments; powers that were further expanded in the 1970s.

4 The increasing ethno-cultural diversity among immigrants in developed countries poses significant challenges in terms of integration into the socioeconomic structures of the countries that host them (Koopmans, 2010). For example, despite formalized equality of chances in terms of school access, several studies show persistent inequalities between students from immigrant families and their peers whose parents are born in the host country. Although free and compulsory schooling allows a large number of students to persevere until the end of secondary school, the majority of students are forced to reduce their aspirations because of educational tracking or streaming (Baum and Flores, 2011; Griga and Hadjar, 2013). In fact, early academic streaming ensures that only a minority accesses postsecondary education courses or programs, leaving the majority relegated to vocational courses leading to the labour market. Most individuals in these circumstances often halt their schooling at this junction (Crul et al., 2012).

5 Nevertheless, the above situation varies between countries. In this regard, Canada is one of the exceptions (Jenkins, Micklewright and Schnepf, 2008). As we will see in the 
next section, a number of studies highlight that Canada is one of the few countries where immigrant students demonstrate academic performances that are comparable to their non-immigrant peers (OECD, 2015; Schnepf, 2007). Moreover, immigrant youth access postsecondary education at a higher proportion than their peers whose parents were born in Canada (Finnie and Mueller, 2010; Picot 2012; Thiessen 2009). However, significant disparities persist among immigrant communities, as evidenced by other works (Abada and Ram, 2009; Kamanzi et al., 2016; Thiessen, 2009). Notably, some immigrant communities said to be racialized, that is, socially assigned a racial identity, continue to face mitigated forms of segregation (Henry and Tator, 2009, 2010; Mickelson, 2003).

6 These cross-Canada findings were made evident in the province of Quebec (Mc Andrew et al., 2015; Mc Andrew et al., 2008). On the one hand, young people whose immigrant parents are from European, Asian or Arab countries have similar or better educational pathways compared to those of their peers whose parents are Canadian-born. On the other hand, those whose parents come from Sub-Saharan Africa, the Caribbean or Latin America tend to have difficult secondary school pathways and have success rates below the provincial average. They are also less likely to attend private schools than youth from other immigrant backgrounds (Mc Andrew et al., 2013). Additionally, youth from the Caribbean are more likely to have experienced exclusion and discrimination during elementary and secondary school education (Collins and Magnan 2018; Lafortune, 2012).

7 Since school performance varies by parental region of origin, this study posits that achievement disparities in basic education translate into postsecondary education pathway differences. Specifically, it assumes that postsecondary pathways vary depending on the migratory origin of students' parents. Prior to validating this hypothesis, we propose an analytical framework based on the concept of educational pathways, as well as a summary description of the Quebec school system structure.

\section{Youth from immigrant backgrounds and the supply of educational pathways in Canada}

8 While the social integration of immigrants is largely measured by their access to quality jobs, which itself is based primarily on the level and quality of their training (Ichou, 2014), international research highlights the segregation (Levels, Dronkers and Kraaykamp, 2008; Söhn and Özcan, 2006), and marginalization (Felouzis, Liot and Perroton, 2005; Cutler, Glaeser and Vigdor, 2007) they experience in the educational systems of their host countries. It is clear that political will is far from evident in many countries. Indeed, some tolerate and even legitimize the culture and practice of marginalization of immigrant students to varying degrees (Buchmann and Parrado, 2006). In several European countries, students of immigrant origins are concentrated in less-privileged neighbourhoods where education is of lower quality (Schnell and Azzolini, 2015), as evidenced, for example, by studies by Auernheimer (2006) in Germany, Schneeweiss (2013) in Austria, as well as Schnell and Azzolini (2015) in Mediterranean countries (Italy, Greece, Portugal, Spain). From generation to generation, these forms of segregation perpetuate educational and socioeconomic inequalities between youth from immigrant communities and their peers from the host society. The former have inferior educational outcomes in basic education (elementary 
and high school), as demonstrated by several comparative studies using international test results (Dronkers and van der Velden; Dustmann, Frattini and Lanzara, 2011; Hochschild and Cropper, 2010; OECD, 2006; Schnepf, 2007). Thereafter, the chances of accessing and graduating from postsecondary education for young immigrants are reduced. However, the situation varies considerably depending on the societal context, as the above studies show. While differences are much more pronounced in countries such as Belgium, Germany, Switzerland and France, to name a few, they appear relatively moderate in Anglo-Saxon countries (United States, Canada, Australia and New Zealand) (Buchmann and Parrado, 2006). In this regard, Australia and Canada are exceptions, with immigrant students performing at levels comparable to their nonimmigrant peers.

In the case of Canada, the first explanation proposed for understanding this exceptional situation relates to the provisions of its immigration policies, which base immigrant selection on their educational capital (Boyd, 2002) and promote integration and multiculturalism over assimilation and monoculturalism (Ghosh, 2004; Harles, 1997, 2004). This political commitment, enshrined in the Canadian Multiculturalism Act, is reflected in a culture of tolerance rooted in Canada's history (Bloemraad, 2012).

Unlike similar countries, Canada's immigration policies focus on multiculturalism, that is, respect for, and appreciation of cultural differences. At the local level, the success of immigrants is due to the principle of, and measures for equity. Whether born in Canada or abroad, all Canadian students of immigrant origins attend the same institutions as non-immigrants and receive the same training. Furthermore, this equal access is enhanced by the provision of additional resources and services to support the integration of newcomers or those with particular difficulties (Shakya, Guruge, Hynie, Akbari, Malik, Htoo, Azza, Mona, Murtaza and Alley, 2010; Simich, Beiser, Stewart and Mwakarimba, 2005). Among these measures, the authors cite welcoming classes, regular language integration, and free French or English courses.

11 The second explanation, which complements the first, refers to the characteristics of the immigrants themselves and the criteria for their selection. The majority of Canadian immigrants is from the economic class and is selected on the basis of education and job skills. On average, they are more educated than the rest of the population (King and Newbold, 2007). Studies show that Canada, Australia and the United Kingdom are the three countries that place greater emphasis on these criteria at the time of selection (Lowell, 2005; Narada and Rieger, 2010). Thus, the educational performance of immigrant students is largely attributable to the influence of their parents' education. In fact, it is a source of various forms of capital (social, cultural) mobilized by families and students in their schooling (Boyd, 2002; Hochschild and Cropper, 2010; Rothon, Heath and Lessard-Phillips, 2009). For many immigrant families, education is virtually the only means envisaged to achieve the social integration of their children in the host country. It also sets the stage for social mobility that may enable them to regain the socioeconomic status they had prior to immigration (Ichou, 2014). Nevertheless, while Canadian policies promote the professional integration of immigrants, these individuals are not invulnerable to segregation, and often need more education than their non-immigrant peers to access equivalent jobs (Reitz, 2001). Since postsecondary education access is a preferred strategy for achieving this goal, educated parents are better equipped to structure their children's educational pathways (Hao and Bonstead-Bruns, 1998). Despite the undeniable progress recognized in Quebec and, 
more broadly, in Canada, there are still significant disparities in academic success between students from immigrant backgrounds, according to the geographical region of origin of their parents. These disparities take on many forms, such as unequal access, unequal perseverance and graduation or, more broadly, unequal educational outcomes. This article focuses on the latter form of educational disparity.

\section{Differentiation of educational pathways and democratization of postsecondary education}

12 All education systems are organized in stages, which are in turn divided into educational streams and curricula. The structure of formal pathways can be rigid or somewhat flexible, in contrast. In many developed societies, the transition from primary to secondary education is automatic and mandatory. However, this is not the case for the transition from secondary to postsecondary education. In fact, not only is it conditional to students' decisions, but also and above all, it rests heavily on the institutional rules governing student selection and orientation in various secondary school streams. In many countries, secondary education is divided into general and vocational tracks. The former prescribes a continuation to postsecondary education, while the latter sets the stage for leaving the school system and entering the labour market. Educational systems, thus set a standard for a regulated, and inevitably, linear route from primary school to postsecondary education (Picard, Trottier, and Doray, 2011).

13 Although academic selection and tracking are theoretically based on students' skills and choices, studies in various social contexts have shown that the assignment of students into these two streams is more reflective of social inequalities through the mediation of academic achievement and aspirations (Duru-Bellat, Kieffer, and Reimer, 2010; Felouzis, 2014). Hence, when children from wealthy families are mostly steered toward general streams and those from modest families toward vocational streams, secondary education becomes a vehicle for academic segmentation (Lucas, 2001) and postsecondary education becomes an instrument for the production and reproduction of social inequalities (Alon, 2009). This is reinforced by the mobilization and interaction of different forms of capital (cultural, social, and economic) that benefit middle and upper class families (Lynch and O'Riordan, 1998). These families tend to place high value on postsecondary education and mobilize the financial resources to ensure that their children attend the best facilities and receive the best education possible. Additionally, they have access to more information and knowledge that allow them to ensure structured mentoring and follow-up that support academic achievement and perseverance (Reay, 2014).

14 To minimize this form of segregation maintained by educational selection and streaming, which most often affects students from disadvantaged backgrounds (namely ethno-cultural minorities from immigrant backgrounds), many countries have instituted measures leading to greater flexibility in terms of admission requirements. This encompasses the diversification of student pathways, which may often be nonlinear (Picard, Trottier, and Doray, 2011). These can include, for example, a change in orientation facilitated by a shift from a general to a vocational stream; a step backward to a less advanced level for the purpose of catching-up; or resuming studies after a period of interruption (Charbonneau, 2006). This structural flexibility makes it possible 
to institutionalize pathways traditionally considered "atypical" (Boutinet, 2007) or "erratic" (Bloomer and Hodkinson, 2000), in contrast to prescribed pathways, leaving more room for educational pathway individualization (Picard, Trottier, and Doray, 2011).

Pathway diversification manifests through the creation of somewhat easier bridges and linkages between secondary, vocational, and postsecondary education. This leads to greater opportunities for postsecondary education access and thus responds to increased social demand for such education (Hoelscher et al., 2008; Maclean and Pavlova, 2013). This restructuring of educational systems has led to the multiplication of linear and non-linear pathways. The former are distinguished by a continuous or "regular" process leading to postsecondary education, while the latter are discontinuous and punctuated by bifurcations, often combining vocational and general training programs (Boutinet, 2007). In other words, students are able to effectuate different combinations of programs or streams as they proceed with their individual educational projects. In some cases, this flexibility allows students the opportunity to modify their choices and thus readjust or reorient their academic and professional plans according to their experiences and timeline (Bloomer and Hodkinson, 2000). In others, it offers an opportunity to catch-up for those previously not able to enrol in a program or stream they initially aimed for. From this perspective, pathway diversification is justly regarded as an instrument for improving the democratization of postsecondary education (Hoelscher et al., 2008; Maclean and Pavlova, 2013).

Nonetheless, the importance of non-linear pathways and their effect on the democratization of postsecondary education tend to vary considerably across educational systems and the public policies that structure them (Kamanzi et al. 2014; Powell et al., 2009). In other words, the influence of educational diversification and its contribution to diminishing social reproduction is still dependent on national and local contexts (Kamanzi et al., 2017). Hence, this anchoring in the "local" context of educational systems incites the study of pathway differentiation according to relevant political scales. In Canada, the scale is essentially provincial, which entails the constitutional responsibility for education, but also and especially the cities where the vast majority of immigrants settle.

\section{Organization of education pathways to postsecondary education in Quebec}

In Quebec, the differentiation and diversification of pathways leading to postsecondary education were instituted by the Parent reform (named after the chairman of the commission that drafted the project, Monseigneur Alphonse-Marie Parent) in the mid-1960s to strengthen the democratization of education (Henripin, 1999). Since, secondary education unfolds in two cycles. The first cycle is two years in duration while the second is three years. During the second cycle, students can pursue a general education program leading to a Secondary School Diploma (SSD) or veer toward vocational training leading to a Diploma of Vocational Studies (DVS). However, in practice, only a very small number of students choose vocational education, which is made evident by the average age of students in this stream: 26 years of age. Programs for students with academic difficulties are also available, which lead to vocational 
diplomas. These students may also pursue their studies in general adult education. Hence, there is a possibility of pathway differentiation even at the secondary level.

After secondary school, students who wish to pursue postsecondary education must apply for admission to a General and Vocational College (known by its French acronym, CEGEP: Collège d'enseignement général et professionnel), the first level of tertiary education serving as a bridge between secondary school and university. In a North American context, it is the equivalent of a community college in the United States and the rest of Canada. However, unlike the latter, CEGEP is not parallel to the university stream, but rather a lower level of training required to access university. Moreover, the SSD and DVS are equivalent in theory, but in reality they are not. Vocational graduates who wish to continue their studies in a CEGEP are required to successfully complete complementary courses in the general education program in order to obtain the prerequisites required by CEGEPs. As a result, two student profiles qualify for CEGEP admission - general secondary school graduates with linear pathways, and those with dual training (professional and general) whose pathways are somewhat non-linear and are predominately adult students returning to school. In addition, CEGEP is itself divided into pre-university and technical programs. As the name suggests, the first consists of a two-year program that prepares students for university. The second lasts three years and provides professional training for future middle managers and senior technicians. Both streams provide access to university.

Figure 1: Organization of the education system in Québec

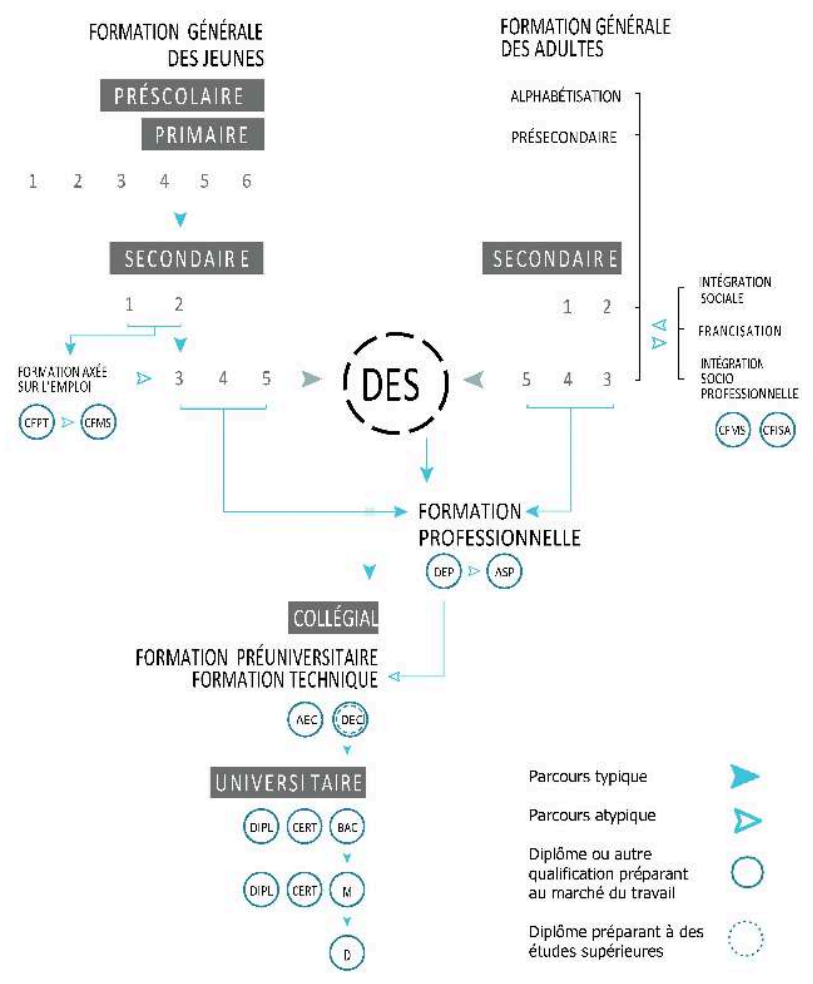

Source: Ministère de l'Éducation, du Loisir et du Sport (http://www.education.gouv.qc.ca/references/ publications/resultats-de-la-recherche/detail/article/etudier-au-quebec/) 


\section{Methodology}

\section{Data Sources and Sample}

19 Most of the data utilized in this article were obtained from the administrative data records of the Quebec Ministry of Education. The initial sample consists of 47,749 subjects from two cohorts of students who entered secondary school in 1994-95 $(n=23,665)$ and 2002-03 $(n=24,084)$ respectively, and who were each observed over a 10year period. The first cohort entered secondary school shortly before the implementation of the "Pedagogical Renewal" in 1996-97; the second largest in Quebec's history after the fundamental reform introduced in 1964, known as the "Parent Reform." The second cohort is the first generation of the most recent reform. The choice of these two cohorts is intended to take into account the impact of the 1996-97 reform, which was primarily aimed at increasing the democratization of education by improving success at all levels of education and making postsecondary education more accessible. Among its strategies, the reform focused on pathway individualization and diversification in order to reduce dropout rates, particularly in secondary schools. Disadvantaged and multi-ethnic areas were specifically targeted. For each of the two cohorts, the sub-sample represents $25 \%$ of the total student population.

Depending on neighbourhood of residence, the analysis shows that about $95 \%$ of immigrant-origin students in this sample lived in the city of Montreal and its suburbs. Since the study compares immigrant students to non-immigrants, the analysis will be limited to students whose parents resided in that region to avoid geographical and socioeconomic context bias. The sub-sample retained consists of 20,387 students of whom 5,334 (26\%) have at least one first-generation immigrant parent, i.e., foreignborn. Table 1 provides a general profile of the sub-sample. 
Table 1: Distribution of Subjects by Parental Geographical Region of Origin

\begin{tabular}{|c|c|c|c|c|c|c|}
\hline & \multicolumn{2}{|c|}{ 1994-1995 cohort } & \multicolumn{2}{|c|}{ 2002-2003 cohort } & \multicolumn{2}{|l|}{ Total } \\
\hline & $\mathrm{N}$ & $\%$ & $\mathrm{~N}$ & $\%$ & $\mathrm{~N}$ & $\%$ \\
\hline Canada & 7,188 & 75.18 & 7,865 & 72.14 & 15,053 & 73.84 \\
\hline Mixed & 679 & 7.16 & 999 & 9.16 & 1,678 & 8.23 \\
\hline East Asia & 94 & 0.99 & 117 & 1.07 & 211 & 1.03 \\
\hline Southeast Asia & 286 & 3.02 & 370 & 3.39 & 656 & 3.22 \\
\hline North Africa & 312 & 3.29 & 450 & 4.13 & 762 & 3.74 \\
\hline Sub-Saharan Africa & 48 & 0.51 & 110 & 1.01 & 158 & 0.77 \\
\hline Europe & 388 & 4.09 & 349 & 3.20 & 737 & 3.62 \\
\hline Latin America and the Caribbean & 490 & 5.17 & 642 & 5.89 & 1,132 & 5.55 \\
\hline All & 9,485 & 100.00 & 10,902 & 100.00 & 20,387 & 100.00 \\
\hline
\end{tabular}

Source: Quebec Ministry of Education, authors' calculations.

21 Given that the data are extracted from student files as opposed to student or parent surveys, they are methodologically limited. Thus, the database does not contain information pertaining to certain factors that structure educational pathways such as student school experiences and perceptions, or relationships between students and various school actors (school staff, parents peers, etc.). Due to confidentiality, the database also does not contain information about students' academic performance. To fill some of these gaps, we supplemented the database with some information available from the 2001 and 2006 Censuses of Canada in order to characterize the students' socioeconomic situation. For purposes of this article, the latter consists of the median household income in the neighbourhood of residence, as well as the percentage of university graduates.

For each cohort, the database contains longitudinal data allowing for the study of educational pathways of students over a 10-year period, at a time when the majority was 22 years old, i.e. up until 2004-2005 for the first cohort, and 2012-2013 for the second. It also contains information on specific sociodemographic characteristics (gender, parental country of origin) and educational characteristics (types of institutions attended at each level of training and whether or not there was an academic interruption) allowing for the analysis of these pathways.

\section{Variables}

23 The dependent variable at the heart of this article is the academic pathway to postsecondary education (CEGEP or university). It was measured by the educational pathway undertaken during and after secondary school. The database we used allowed 
us to identify students who had continued their studies to CEGEP and who subsequently attended university. In addition, it was possible to distinguish between those who undertook linear and non-linear pathways in order to access CEGEP. Linear pathways include students who, after graduating from secondary school, continued their studies in CEGEP, whether they had pursued university or not. Conversely, non-linear pathways include those who, after earning a SSD, enrolled in a parallel or equivalent program. These students entered a general program after earning a DVS or vice versa. Under this criterion, the subjects in our sample are grouped into four categories of students:

- no postsecondary education access: those who, after secondary school, terminated their studies, at least for the observation period;

- linear pathway ending in CEGEP: those who, after obtaining a secondary school diploma in general education, continued their studies in a technical or pre-university CEGEP program, but did not pursue university studies;

- linear pathway to university: those who, after obtaining a secondary school diploma in general education, went to CEGEP and then continued their studies in university;

- non-linear pathway to CEGEP: those who, prior to enrolling in CEGEP, completed dual secondary (both general and vocational) training.

The independent variable is the geographical region of origin of the students' parents. It was measured by the country of birth of both parents. In order to obtain sufficient numbers for the analysis, countries were grouped by geographical region. Drawing on the categories used in some previous studies (Finnie and Mueller, 2008; Kamanzi et al., 2016; Thiessen, 2009), and taking into account the number of subjects by parental country and region of origin, students were grouped into eight categories: (1) Canada, (2) mixed: one immigrant parent and the other Canadian by birth, (3) Europe and Anglo-Saxon countries, (4) East Asia, (5) Southeast Asia and Pacific Islands, (6) North Africa and the Middle East, (7) Sub-Saharan Africa and (8) Latin America and the Caribbean. Table 1 describes the sample distribution for this variable.

Control variables. Three variables related to secondary schooling for which preliminary analyses showed a significant influence on educational outcomes were included in the analyses; (1) type of secondary school attended (private or public), (2) age upon secondary school entry, indicating whether or not the student had an academic delay, and (3) difficulty adapting to school or to learning. Student records contain a code specifying whether students had any adjustment or learning difficulties, as well as the age at which students entered secondary school. In addition, two sociodemographic variables were also considered: student gender and socioeconomic origin. The latter was measured by two indicators linked to students' home community characteristics (census unit); (1) the percentage of university graduates and (2) the median income per household. These two variables were taken from the 2001 Canadian Census data for the 1994-1995 cohort and the 2006 Census for the 2002-2003 cohort.

\section{Model}

As a first step, descriptive analyses were conducted to determine the overall postsecondary pathway portrait based on the independent variable. Subsequently, a multinomial logistic regression analysis (Allison, 2003) was conducted to estimate the 
relative influence of sociodemographic and school characteristics. The model choice is justified by the fact that the dependent variable is categorical. $p(y=0)$ : no postsecondary education; (2) $p(y=1)$ : linear pathway ending in CEGEP; (3) $\mathrm{p}(\mathrm{y}=2)$ : linear pathway to university; (4) $\mathrm{p}(\mathrm{y}=3)$ : non-linear pathway to CEGEP. Statistically, the purpose of the analysis is to estimate the influence of the students' parental geographical region of origin on the likelihood of undertaking one of these pathways as a result of factors $\mathrm{X}_{1}, \mathrm{X}_{2}, \ldots, \mathrm{X}_{\mathrm{k}}$. Modeling by the logit function makes it possible to compare the probability associated with each of these pathways with that of the opposite, that is to say, not accessing postsecondary education or $\mathrm{p}(\mathrm{y}=0)$. This comparison is summarized in three equations:

$$
\begin{aligned}
& \operatorname{logit}\left[p\left(y=1 \mid X_{1}, X_{2}, \ldots X_{k}\right)\right]=\ln \frac{p\left(y=1 \mid X_{1}, X_{2} \ldots X_{k}\right)}{p\left(y=0 \mid X_{1}, X_{2} \ldots X_{k}\right)}=\alpha_{1}+\beta_{11} \mathrm{X}_{1}+\beta_{21} \mathrm{X}_{2}+\ldots+\beta_{\mathrm{k} 1} \mathrm{X}_{\mathrm{k}}(1), \\
& \operatorname{logit}\left[p\left(y=2 \mid X_{1}, X_{2}, \ldots X_{k}\right)\right]=\ln \frac{p\left(y=2 \mid X_{1}, X_{2} \ldots X_{k}\right)}{p\left(y=0 \mid X_{1}, X_{2} \ldots X_{k}\right)}=\alpha_{2}+\beta_{12} \mathrm{X}_{1}+\beta_{22} \mathrm{X}_{2}+\ldots+\beta_{\mathrm{k} 2} \mathrm{X}_{\mathrm{k}}(2), \\
& \operatorname{logit}\left[p\left(y=3 \mid X_{1}, X_{2}, \ldots X_{k}\right)\right]=\ln \frac{p\left(y=3 \mid X_{2}, X_{2} \ldots X_{k}\right)}{p\left(y=0 \mid X_{2}, X_{2} \ldots X_{k}\right)}=\alpha_{3}+\beta_{13} \mathrm{X}_{1}+\beta_{23} \mathrm{X}_{2}+\ldots+\beta_{\mathrm{k} 3} \mathrm{X}_{\mathrm{k}}(3),
\end{aligned}
$$

In these same equations, $\alpha_{1}, \alpha_{2}$ and $\alpha_{3}$ represent the ordinate at the origin or the constant for equations (1), (2) and (3) respectively, while $\beta_{1,}, \beta_{2}, \ldots, \beta_{\mathrm{k}}$ represent the regression coefficients respectively associated with factors $X_{1}, X_{2}, \ldots, X_{k}$ for the same equations.

In order to facilitate interpretation, the regression coefficients have been transformed into odds ratios (OR) as follows:

$$
\begin{aligned}
& \mathrm{RC}_{1}=\operatorname{Exp}\left(\alpha_{1}+\beta_{11} \mathrm{X}_{1}+\beta_{21} \mathrm{X}_{2}+\ldots+\beta_{\mathrm{k} 1} \mathrm{X}_{\mathrm{k}}\right)=e^{\alpha_{1}+\beta_{11} X_{1}+\beta_{21} X_{2}+\ldots+\beta_{\mathrm{k} 1} X_{k}} \\
& \mathrm{RC}_{2}=\operatorname{Exp}\left(\alpha_{2}+\beta_{12} \mathrm{X}_{1}+\beta_{22} \mathrm{X}_{2}+\ldots+\beta_{\mathrm{k} 2} \mathrm{X}_{\mathrm{k}}\right)=e^{\alpha_{2}+\beta_{12} X_{1}+\beta_{22} X_{2}+\ldots+\beta_{\mathrm{k} 2} X_{k}} \\
& \mathrm{RC}_{3}=\operatorname{Exp}\left(\alpha_{3}+\beta_{13} \mathrm{X}_{1}+\beta_{23} \mathrm{X}_{2}+\ldots+\beta_{\mathrm{k} 3} \mathrm{X}_{\mathrm{k}}\right)=e^{\alpha_{3}+\beta_{13} X_{1}+\beta_{23} X_{2}+\cdots+\beta_{\mathrm{k} 3} X_{k}}
\end{aligned}
$$

\section{Results}

After secondary school, young Quebecers undertake a variety of educational pathways. According to the data utilized (Table 2), ten years after entering secondary school, almost two-thirds (64.92\%) of students had attended a postsecondary institution at one time or another. Of these, $34.13 \%$ had attended CEGEP and another $30.80 \%$ had pursued university studies. However, attendance rates vary depending on the parental geographical region of origin. It is significantly higher among youth with families from East Asia (80.20\%), North Africa and the Middle East (74.03\%), but relatively lower among those from Latin America and the Caribbean (57.77\%). 
Table 2: Distribution of Subjects by Parental Geographical Region of Origin and Type of Academic Pathway to Postsecondary Education (PSE)

\begin{tabular}{|c|c|c|c|c|c|c|}
\hline & $\begin{array}{l}\text { No HE } \\
\text { Pathwoy }\end{array}$ & $\begin{array}{l}\text { Access to } \\
\text { PSE }\end{array}$ & $\begin{array}{l}\text { Pathway } \\
\text { (1) }\end{array}$ & $\begin{array}{l}\text { Pathway } \\
\text { (2) }\end{array}$ & $\begin{array}{l}\text { Pathway } \\
\text { (3) }\end{array}$ & \\
\hline & $\%$ & $\%$ & $\%$ & $\%$ & $\%$ & $\mathrm{~N}$ \\
\hline Canada & 35.35 & 64.65 & 25.31 & 29.59 & 9.75 & 14,594 \\
\hline $\begin{array}{l}\text { Only one parent } \\
\text { bom in Canada }\end{array}$ & 35.81 & 64.19 & 24.04 & 33.64 & 6.51 & 1614 \\
\hline East Asia & 19.80 & 80.20 & 20.30 & 57.92 & 1.98 & 202 \\
\hline $\begin{array}{l}\text { Southeast Asia and } \\
\text { Pacific Islands }\end{array}$ & 32.18 & 67.82 & 25.55 & 38.17 & 4.10 & 634 \\
\hline $\begin{array}{l}\text { North Africa and the } \\
\text { Middle East }\end{array}$ & 25.93 & 74.03 & 21.93 & 44.83 & 7.31 & 725 \\
\hline Sub-Saharan Africa & 36.30 & 63.70 & 23.97 & 33.56 & 6.16 & 146 \\
\hline $\begin{array}{l}\text { Europe / Anglo- } \\
\text { Saxon countries }\end{array}$ & 33.19 & 66.81 & 23.57 & 36.40 & 6.83 & 717 \\
\hline $\begin{array}{l}\text { Latin America and } \\
\text { the Caribbean }\end{array}$ & 42.23 & 57.77 & 19.70 & 28.22 & 9.85 & 1,056 \\
\hline Everyone & 35.07 & 64.92 & 25.12 & 30.80 & 9.01 & 19,688 \\
\hline
\end{tabular}

Pathway (0): pathway that ends at high school

Pathway (1): linear secondary CEGEP;

Pathway (2): linear secondary university;

Pathway (3): non-linear secondary CEGEP.

Source: Quebec Ministry of Education, authors' calculations.

31 In addition to the highest level of study (CEGEP or university) pursued, students are differentiated by the type of pathway undertaken. According to the analysis, $55.92 \%$ of students undertake a linear pathway (25.12\% until CEGEP and 30.80\% until university). Almost one in ten (9.01\%) students accesses CEGEP via a non-linear pathway. Recalling that this category of students is composed of those who, after obtaining a high school diploma in a vocational training program, have taken courses in a general education program and vice versa. However, additional analyses reveal that the majority of these students $(68 \%)$ are vocational training graduates who have taken courses in a general education program in order to gain eligibility for CEGEP.

While linear or non-linear pathway choice theoretically rests with students, the results reveal significant differences by parental geographical region of origin. Overall, with the exception of those from Latin America and the Caribbean (9.85\%), students with immigrant parents are less likely to undertake non-linear pathways than their peers whose two parents are Canadian-born (9.75\%). The proportion is markedly low among those whose parents come from East Asian countries (1.98\%), as well as those from South Asia and the Pacific Islands (4.10\%). Conversely, students from immigrant families from these regions undertake linear pathways to university at a relatively higher proportion than their peers from Canadian-born parents (29.59\%): 57.92\% from East Asia, 44.83\% from North Africa and the Middle East, $44.83 \%$ from Southeast Asia, $36.40 \%$ from Europe and Anglo-Saxon countries and 34\% from Sub-Saharan Africa. The 
overall situation appears to be comparable, however, to the linear pathway to CEGEP without university access, at least for the observation period. The analysis shows that there are relatively few differences at this level.

\section{Pathway choices strongly modulated by school factors and beyond}

Multinomial analyses (Table 3) examine whether the observed differences by parental geographical region of origin in the pathways are statistically significant, and to what extent they are attributable to this variable or to the effect of students' educational background and sociodemographic characteristics. Model 1 includes only the geographical region of origin of the students' parents. The results add detail to those from the previous descriptive analysis (Table 2), indicating significant differences in linear pathways and, to a lesser extent, in non-linear pathways.

In terms of linear pathways, the results reveal three main findings. Firstly, the differences between immigrant and non-immigrant students are significantly higher at the university level than at the CEGEP level. Secondly, the situation is highly variable within the immigrant group itself. Thirdly, significant differences are found mainly among second-generation immigrants, whereas there is relatively little difference among first-generation immigrants, especially at the CEGEP level. Thus, compared to non-immigrants, the probability of undertaking this pathway is nine times higher $(\operatorname{Exp}(\beta)=8.96)$ for second-generation immigrants from East Asia, and almost four times higher for those from South-East Asia and the Pacific Islands $(\operatorname{Exp}(\beta)=3.56)$, North Africa and the Middle East $(\operatorname{Exp}(\beta)=3.79)$. Nevertheless, it is noteworthy that children of immigrants from Latin America and the Caribbean are the exception: they are less likely to follow linear pathways to university $(\operatorname{Exp}(\beta)=0.89)$, compared to nonimmigrants (1.00).

With respect to non-linear pathways, the situation is somewhat reversed, as aforementioned: with the exception of those from Sub-Saharan Africa, immigrants are less likely to undertake these types of pathways. As such, the analysis begets two observations. The significant differences observed are once again quite variable according to parental geographical region of origin, but are mainly observed among first-generation immigrants, whereas the situation is rather comparable among those of the second generation and non-immigrants. 
Table 3: Multinomial Regression Coefficients - Odds Ratio

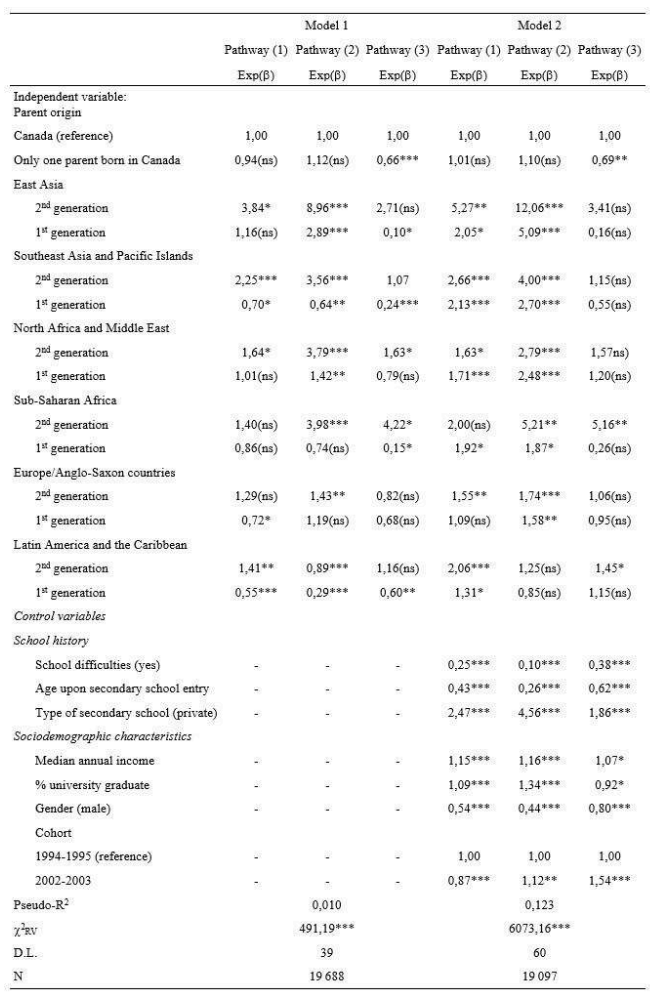

Pathway (1): Linear secondary CEGEP

Pathway (2): Linear secondary University

Pathway (3): Non-linear secondaryCEGEP

${ }^{\star} p<0.05 ;{ }^{*} p<0.01 ;{ }^{\star \star *} p<0.001$; LR: likelihood ratio; DF: Number of degrees of freedom.

Source: Quebec Ministry of Education, authors' calculations.

Models 2 and 3 take into account the respective variables related to students' educational and sociodemographic characteristics. The results show that these variables have a significant influence on postsecondary education access and pathway choice. Students who experienced educational lag or academic difficulties prior to entering secondary school, as well as those who had only attended a public institution (as opposed to a private school) are significantly less likely to access postsecondary education, whether via a linear or non-linear pathway. The same is true for boys: they are less likely than girls to pursue postsecondary education, whether through linear or non-linear pathways. Finally, the higher the median annual household income, as well as the percentage of university graduates in the neighbourhood of residence of the student's parents, the greater the probability of undertaking a linear pathway, especially to university.

The introduction of these control variables significantly changes the influence of the students' parental geographical region of origin. With similar educational and sociodemographic characteristics, immigrant youth are significantly more likely to pursue postsecondary studies at both university and CEGEP via linear pathways. However, further analysis shows that this change in outcomes is more attributable to the students' educational background than to their sociodemographic characteristics. In addition, the model highlights two significant differences in non-linear pathways. Compared to students whose parents are Canadian-born, these pathways tend to be more common among those whose parents are immigrants from North Africa or the 
Middle East, as well as from Latin America or the Caribbean. In short, the results support the hypothesis that the pursuit of postsecondary education and the pathways undertaken by Quebec immigrant youth are strongly influenced by the quality of their primary and secondary education.

\section{Discussion}

This study shows that, in Quebec, immigrant students pursue globally postsecondary education at an equal or even higher rate than those whose parents were born in Canada. It confirms the findings of previous studies that highlight the exceptional situation of Canada, and the province of Quebec in particular. As mentioned in the first section, this increased postsecondary education access for immigrants has been attributed to Canadian immigration policies. On the one hand, these policies promote the acceptance of immigrants with socioeconomic integration skills, by basing immigrant selection on educational and occupational qualification criteria (Ferrer, Picot and Ridell, 2014), Studies show that better educated immigrants provide more guidance in terms of their children's education (Abada and Tenkorang, 2009), transfer cultural and social capital to their children that promote academic success and retention, and modulate upward academic and vocational mobility (Ichou, 2014; Thiessen, 2009). The international literature shows that such capital fosters strategic school choices (Erel, 2010; Fanning, Haase and O'Boyle, 2011) and perseverance through postsecondary education (Douglass and Thomson, 2010). Studies also indicate that, at the national and local levels, this selection is secured via measures that promote the integration of immigrants and eliminate, or at least reduce segregation (Berry, 2013). However, we were unable to determine the impact of these measures on the integration of parents.

Moreover, as is the case for other previous research, this study recognizes the limitations of immigration policies and the likely existence of segregation that affects certain immigrant communities, which manifest through rather challenging and fragile educational pathways. Thus, as we have shown, the fact that proportionally, fewer students from immigrant families from Latin America and the Caribbean access postsecondary education is, in part, due to their educational background. Additional analyses (Table 4) show that these students are less likely to attend private schools. On the other hand, they are proportionally more likely to have experienced learning difficulty or special education placement. While their dropout rate is higher compared to others (Mc Andrew et al., 2015; Mc Andrew et al., 2013), the available database only contains students who graduated with a degree or qualification diploma. The presence of school dropouts in the analysis would likely have shown greater differences between these students and others who undertook linear pathways to postsecondary education. In other words, failure to take into account this category of variables carries the risk of overestimating their pathways to postsecondary education. In the same vein, the database did not contain information on academic results, which also determines pathways and postsecondary education access. 
Table 4: High School Characteristics According to Parental Geographical Region of Origin (\%)

\begin{tabular}{lllll}
\hline & $\begin{array}{l}\text { Private } \\
\text { attendance }\end{array}$ & $\begin{array}{c}\text { school Educational } \\
\text { lag }\end{array}$ & $\begin{array}{l}\text { Enrolment } \\
\text { education }\end{array}$ & in special \\
\hline Canada & 26.57 & 16.59 & 10.99 & 14,594 \\
Mixed & 25.27 & 16.51 & 12.51 & 1614 \\
East Asia & 38.86 & 36.97 & 5.69 & 202 \\
South-East Asia & 15.55 & 37.80 & 8.84 & 634 \\
North Africa & 35.56 & 30.31 & 9.06 & 725 \\
Sub-Saharan Africa & 13.92 & 41.77 & 17.72 & 146 \\
Europe & 26.59 & 28.49 & 10.31 & 717 \\
Latin America and the & 19.43 & 44.17 & 17.76 & 1,056 \\
Caribbean & 26.08 & 20.15 & 11.32 & 19,688 \\
All & 26.59 & 28.49 & 10.31 & 717 \\
Europe & 19.43 & 44.17 & 17.76 & 1,056 \\
Latin America and the & & & 11.32 & 19,688 \\
Caribbean & 26.08 & 20.15 & & \\
All & & & & \\
\hline
\end{tabular}

Source: Quebec Ministry of Education, authors' calculations.

In the end, this study allows us to draw two main conclusions. The first is that pathway differentiation contributes to reducing postsecondary education access inequalities. The results show that $9.01 \%$ of young Quebecers undertake non-linear pathways, which represent about $14 \%$ of those who access CEGEP. As previously mentioned, these pathways contribute to increasing postsecondary education access for youth from Latin American and Caribbean immigrant backgrounds - the group with the most unfavourable portrait in this regard: $9.85 \%$ undertake these pathways, which represents $17 \%$ of those who access CEGEP. Although modest, the contribution of nonlinear pathways to postsecondary education access in Quebec is undeniable, as the results show. However, the effect of this differentiation is limited, as inequalities are reconstructed and even tend to be reinforced within postsecondary education itself through pathway choice (Duru-Bellat, Kieffer and Reimer 2010). In other words, quantitative equality can eclipse qualitative inequalities (Prost 1992), because more education does not mean the same education for all (Erlich and Verly, 2010). The pathways to postsecondary education that lead to this differentiation are often marked by a certain hierarchy, and lead to degrees of unequal social value (Erlich and Verly, 2010; Hoelscher et al., 2008). Thus, not only must policies on pathway differentiation be pursued in order to further democratize education access, but measures to harmonize these pathways must be considered, to counter the risk of postsecondary education hierarchization and socioeducational segmentation. Further research should continue in this direction to inform policy on the prospects of linking equal access to education to equal outcomes. In order to take into account recent developments in immigration policies at the provincial and federal levels, researchers could also conduct analyses based on more recent data that we have not been able to access. 


\section{Conclusion}

The objective of this study was to describe and analyze the pathway morphology of young Quebecers from immigrant families toward postsecondary education, as well as the factors that contribute to their structuration. The underlying assumption is that these pathways vary depending on the parental geographical region of origin. To do this, the pathways (linear and non-linear) of students from different immigrant backgrounds were compared to those of their peers whose parents are not immigrants. The results obtained from the selected data provide three general findings. Firstly, between these two categories of students, undertaking a linear or non-linear pathway varies significantly. However, the differences are more pronounced in linear pathways, as opposed to non-linear. Furthermore, in terms of linear pathways, the analysis showed that this difference is significantly higher in university than in CEGEP. In other words, after secondary school, students from immigrant backgrounds are significantly more likely to follow up with CEGEP and university. On the other hand, the difference in non-linear pathways is relatively small, and tends to disappear when the sociodemographic and educational characteristics of students are taken into account. This supports the hypothesis that these pathways contribute to the reduction of inequalities and to the democratization of postsecondary education, as mentioned in the section dedicated to the analytical framework. Secondly, there are significant disparities among immigrant students themselves by parental geographical region of origin. Three groups of students stand out in terms of their linear pathway choices to university; those whose parents come from (1) East Asia; (2) Southeast Asia and the Pacific Islands; and (3) Maghreb and Middle Eastern countries. However, the situation is reversed for those from Latin American and Caribbean origins. The latter are less inclined to follow linear pathways than others. Thirdly, similar differences are observed between first and second-generation immigrants students whose immigrant parents are from the same geographical region. Finally, these observed disparities are in part due to educational background, which is associated with parental geographical region of origin, and acts in interaction with pathway choice.

In short, the results obtained corroborate those of previous studies while providing greater precision. As underscored in the first section, several studies have shown that, unlike other developed countries, young Canadians from immigrant backgrounds attain higher levels of education than their non-immigrant peers (Finnie and Mueller, 2010; Picot, 2012). However, this paper goes farther, and its particular contribution is to have, using the concept of pathways, highlighted the qualitative aspects of these differences. 


\section{BIBLIOGRAPHY}

Abada Eric and Tenkorang Eric (2009) Pursuit of university education among the children of immigrants in Canada: The roles of parental human capital and social capital, Journal of Youth Studies, 12 (2), pp. 185-207.

Allison Paul Davis (2003) Logistic Regression. Using the SAS System. Theory and Application, Cary, NC, SAS Institute Inc., $308 \mathrm{p}$.

Alon Sigal (2009) The evolution of class inequality in higher education: competition, exclusion, and adaptation, American Sociological Review, 74, pp. 731-755.

Auernheimer Georg (2006) The German education system: Dysfunctional for an immigration society, European Education, 37 (4), pp. 75-89.

Baum Sandy and Flores Stella M. (2011) Higher education and children in immigrant families, The Future of Children, 21 (1), pp. 171-193.

Berry John W. (2013) Intercultural relations in plural societies: Research derived from Canadian multiculturalism policy, Canadian Ethnic Studies, 3(2), pp. 1122-1135..

Bloemraad Irene (2012) Understanding "Canadian Exceptionalism" in Immigration and Pluralism Policy, Washington, DC, Migration Policy Institute, [online] last checked on 31/08/2017. URL: http:// www.migrationpolicy.org/research/TCM-canadian-exceptionalism

Bloomer Martin and Hodkinson Phil (2000) The complexity and unpredictability of young people's learning careers, Education \& Training, 42 (2), pp. 68-74.

Boutinet Jean-Pierre (2007) L'espace contradictoire des conduites à projet: entre le projet d'orientation du jeune et le parcours atypique de l'adulte, L'Orientation scolaire et professionnelle, 36 (1), pp. 19-32.

Boyd Monica (2002) Educational offspring: success or segmented assimilation?, International Immigration Review, 36 (4), pp. 1036-1060.

Buchmann Claudia and Parrado Emilio A. (2006) Educational achievement of immigrant-origin and native students: A comparative analysis informed by institutional theory, International Perspectives on Education and Society, 7, pp. 335-366.

Charbonneau Johanne (2006) Réversibilité des parcours scolaires au Québec, Cahiers internationaux de sociologie, 20 (1), pp. 111-131.

Crul Maurice, Schnell Phillipp, Herzog-Punzenberger Barbara, Wilmes Maren, Slootman Marieke and Gómez Rosa Aparicio (2012) School careers of second-generation youth in Europe: Which education systems provide the best chances for success?, in Maurice Crul, Jens Schneider and Frans Lelie Eds., The European Second Generation Compared. Does the Integration Context Matter?, Amsterdam, Amsterdam University Press, pp. 110-165.

Cutler David Matthew, Glaeser Edward Ludwig and Vigdor Jacob L. (2007) When Are Ghettos Bad? Lessons from Immigrant Segregation in The United States, Working Paper 13082, Cambridge, National Bureau of Economic Research, [online] last checked on 31/08/2017. URL: http://www.nber.org/ papers/w13082

Djajic Slobodan (2003) Assimilation of Immigrants: Implications for Human Capital Accumulation of the Second Generation, Journal of Population Economics, 6, pp. 831-845. 
Dronkers Jaap and van der Velden Rolf (2013) Positive but also Negative Effects of Ethnic Diversity in Schools on Educational Performance? An Empirical Test Using PISA Data, in Michael Windzio Ed., Integration and Inequality in Educational Institutions, New York/London/Dordrecht, Springer Science \& Business Media, pp. 71-98.

Douglass John Aubrey and Thomson Gregg (2010) The immigrant's university: A study of academic performance and the experiences of recent immigrant groups at the University of California, Higher Education Policy, 23(4), pp. 451-474.

Duru-Bellat Marie, Kieffer Annick et Reimer David (2010) Les inégalités d'accès à l'enseignement supérieur: le rôle des filières et des spécialités. Une comparaison entre l'Allemagne de l'Ouest et la France, Économie et statistique, 433 (1), pp. 3-22.

Dustmann Christian, Frattini Tommaso and Lanzara Gianandrea (2011) Educational achievement of second generation of immigrant: An international comparison, Discussion paper, London, Centre for Research and Analysis of Migration, Department of Economics, [online] last checked on 31/08/2017. URL: http://www.webmail.norface-migration.org/publ_uploads/NDP_25_11.pdf

Erlich Valérie and Verley Élise (2010) Une relecture sociologique des parcours des étudiants français: entre segmentation et professionnalisation, Éducation et Sociétés: Revue internationale de sociologie de l'éducation, 26 (2), pp. 71-88.

Felouzis Georges (2014) Les inégalités scolaires, Paris, Presses universitaires de France, 128 p.

Felouzis Georges, Liot Françoise and Perroton Joëlle (2005) L'apartheid scolaire: enquête sur la ségrégation ethnique dans les collèges, Paris, Éditions du Seuil, 235 p.

Ferrer Ana, Picot Garnett and Riddell W. Craig (2014) New Directions in Immigration Policy: Canada's Evolving Approach to the Selection of Economic Immigrants, International Migration Review, 48 (3), 846-867.

Finnie Ross and Mueller Richard E. (2010) They came, they saw, they enrolled: Access to postsecondary education by the children of Canadian immigrants, in Ross Finnie, Marc Frenette, Richard E. Mueller and Arthur Sweetman Eds., Pursuing higher education in Canada. Economic, social, and policy dimensions, Kingston, Queen's University Press, pp. 192-216.

Finnie Ross and Mueller Richard E. (2008) The effects of family income, parental education and other background factors to postsecondary education in Canada. Measuring the effectiveness of student aid, MESA project paper, Toronto, Educational Policy Institute, $52 \mathrm{p}$.

Ghosh Ratns (2004) Public Education and multicultural policy in Canada: The special case of Quebec, International Review of Education, 50 (5), pp. 543-566.

Griga Dorit and Hadjar Andreas (2013) Migrant Background and Higher Education Participation in Europe: The Effect of the Educational Systems, European Sociological Review, 30 (3), pp. 275-286.

Hao Linxin and Melissa Bonstead-Bruns (1998) Parent-child differences in Educational expectations and the academic achievement of immigrant and native students, Sociology of Education, 71 (3), pp. 175-198.

Harles John C. (2004) Immigrants integration in Canada and United States, American Review of Canadian Studies, 34 (2), pp. 223-258.

Harles John C. (1997). Integration before assimilation: immigration, multiculturalism and the Canadian polity, Canadian Journal of Political Science/Revue canadienne de science politique, 30, pp. 711-736. 
Henripin Marthe (1999) Différencier le curriculum au secondaire: vers des parcours scolaires stimulants pour tous les jeunes: problématique, situation au Québec, défis pour notre système scolaire, Québec, Conseil supérieur de l'éducation, 193 p.

Henry Frances and Tator Carol (2010) The colour of democracy: racism in Canadian society, Toronto, Nelson Education, 198 p.

Henry Frances and Tator Carol (2009) Racism in the Canadian university: demanding social justice, inclusion, and equity, Toronto, University of Toronto Press, 224 p.

Hochschild Jennifer L. and Cropper Porsha (2010) Immigration regimes and schooling regimes: Which countries promote successful immigrant incorporation?, Theory and Research in Education, 8 (1), pp. 21-61.

Hoelscher Michael, Hayward Geoff, Ertl Hubert and DunbarGoddet Harriet (2008) The transition from vocational education and training to higher education: a successful pathway?, Research Papers in Education, 23 (2), pp. 139-151.

Ichou Mathieu (2014) Who they were there: Immigrants' educational selectivity and their children's educational attainment, European Sociological Review, 30 (6), pp. 750-765.

Jenkins Stephen P., Micklewright John and Schnepf Sylke V. (2008) Social segregation in secondary schools: how does England compare with other countries?, Oxford Review of Education, 34 (1), pp. 21-37.

Kamanzi Pierre Canisius, Bastien Nicolas, Doray Pierre and Magnan Marie-Odile (2016) Immigration et cheminements scolaires aux études supérieures au Canada: qui y va et quand? Une analyse à partir du modèle de risque proportionnel de Cox, Canadian Journal of Higher Education, 46 (2), pp. 209-232.

Kamanzi Pierre Canisius, Guégnard Christine, Imdorf Christian, Koomen Marteen and Murdoch Jake (2014) Démocratisation de l'enseignement supérieur et emprise des parcours: comparaison entre la France, la Suisse et le Canada, Télescope, 20 (2), pp. 170-188.

Kamanzi Pierre Canisius et Murdoch Jake (2011) L'accès à un diplôme universitaire chez les immigrants, in Kanouté Fassal et Lafortune Gina Éds., Familles québécoises d'origine immigrante: les dynamiques de l'établissement, Montréal, Presses de l’Université de Montréal, pp. 145-158.

Kamanzi Pierre Canisius, Pilote Annie, Uzenat Morgane and Gris Sandrine (2017) La démocratisation des études supérieures à l'aune de la différenciation et l'individualisation des parcours scolaires au Québec, Orientation scolaire et professionnelle, 46 (4), pp. 571-594.

King Karen M. and Newbold Bruce K. (2007) Internal migration dynamics of Canadian immigrant gateway: Toronto as an origin, way-station and destination between 1991 and 2001, Canadian Journal of Regional Sciences/Revue canadienne des sciences régionales, 30 (2), pp. 243-262.

Koopmans Ruud (2010) Trade-Offs between Equality and Difference: Immigrant Integration, Multiculturalism and the Welfare State in Cross-National Perspective, Journal of Ethnic and Migration Studies, 36 (1), pp. 1-26.

Lafortune Gina (2012) Rapport à l'école et aux savoirs scolaires de jeunes d'origine haïtienne en contexte scolaire défavorisé à Montréal, Thèse de doctorat inédite, Montréal, Université de Montréal.

Levels Mark, Dronkers Jaap and Kraaykamp Gerbert (2008) Immigrant children's educational achievement in western countries: origin, destination, and community effects on mathematical performance, American Sociological Review, 73, pp. 835-853. 
Li Peter S. (2003) Deconstructing Canada's discourse of immigrant integration, Journal of International Migration and Integration, 4 (3), pp. 315-333.

Lowell Lindsay B. (2005) Policies and regulations for managing skilled international migration for work, New York, United Nations, Population Division Department of Economic and Social Affairs United Nations Secretariat, $24 \mathrm{p}$.

Lucas Samuel L. (2001) Effectively maintained inequality: education transitions, track mobility, and social background effects, American Journal of Sociology, 106 (6), pp. 1642-1690.

Lynch Kathleen and O'riordan Claire (1998) Inequality in higher education: A study of class barriers, British Journal of Sociology of Education, 19 (4), pp. 445-478.

Maclean Rupert and Pavlova Margarita (2013) Vocationalization of secondary and higher education: pathways to the world of work, in UNESCO-UNEVOC International Centre for Technical and Vocational Education and Training Eds., Revisiting global trends in TVET: Reflections on theory and practice, Bonn, UNESCO-UNEVOC, pp. 40-84.

Martel Laurent and D'Aoust Carol (2016) L'immigration permanente et temporaire au Canada de 2012 à 2014: Rapport de l'état de la population du Canada, Catalogue 91-209-X, Statistique Canada, 14 p., [en ligne]. URL: https://www150.statcan.gc.ca/n1/fr/catalogue/91-209X201600114615

Mc Andrew Marie, Balde Alhassane, Bakhshaei Mahsa, Tardif-Grenier Kristel, Audet Geneviève, Armand Françoise, Guyon Sylvie, Ledent Jacques, Lemieux Georges, Potvin Maryse, Rahm Jrène, Vatz-Laaroussi Michèle, Carpentier Alain, and Rousseau Cécile (2015) La réussite éducative des élèves issus de l'immigration: dix ans de recherches et d'intervention, Montréal, Presses de l'Université de Montréal, 365 p.

Mc Andrew Marie, Garnett Bruce, Ledent Jacques and Ungerleider Charles (2008) La réussite scolaire des élèves issus de l'immigration: une question de classe sociale, de langue ou de culture ?, Éducation et culture, 36 (1), pp. 177-196.

Mc Andrew Marie, Ledent Jacques, Murdoch Jake et Ait-Saïd Rachid (2011) La réussite scolaire des élèves issus de l'immigration au secondaire, Rapport final, Montréal, Ministère de l'Éducation, du Loisir et du Sport du Québec, 141 p.

Mc Andrew Marie, Ledent Jacques, Murdoch Jake, Ait-Saïd Rachid and Alhassane Balde (2013) Le profil et le cheminement scolaire des jeunes Québécois issus de l'immigration au secondaire: Un portrait statistique, Cahiers québécois de démographie, 42 (1), pp. 31-55.

Ministère de l'Immigration, de la Diversité et de l'Inclusion (MIDI) (2015). Portraits statistiques. L'immigration permanente au Québec selon les catégories d'immigration et quelques composantes 2010-2014, Québec, Gouvernement du Québec.

Narada Luckanachai and Rieger Matthias (2010) Making Migration a Development Factor: The Case of North and West Africa. A Review of International Policies, A Working Paper, Geneva, Programme for the Study of Global Migration, Graduate Institute of International and Development Studies, $52 \mathrm{p}$. OECD (2006) Where immigrant students succeed. A comparative review of performance and engagement in PISA 2003, Paris, OECD.

OCDE (2017) Perspectives de migrations internationales 2017, Paris, OCDE, 384 p.

OECD (2015) Indicators of Immigrant Integration 2015, Paris, OECD, [online] last checked on 31/082017. URL: http://www.oecd.org/els/mig/Indicators-of-Immigrant-Integration-2015.pdf 
Picard France, Trottier Claude and Doray Pierre (2011) Conceptualiser les parcours scolaires à l'enseignement supérieur, L'orientation scolaire et professionnelle, 40 (3), pp. 1-19.

Picot Garnett (2012) Immigrant status and secondary school performance as determinants of postsecondary participation: A Comparison of Canada and Switzerland, OECD Education Working Papers 77, OECD Publishing, 49 p., [online]. URL: http://dx.doi.org/10.1787/5k9909jhz4wl-en

Powell Justin J.W, Coutrot Laurence, Graf Lukas, Bernhard Nadine, Kieffer Annick and Solga Heike (2009) Comparing the relationship between vocational and higher education in Germany and France, Discussion Papers, Berlin, Wissenschaftszentrum Berlin für Sozialforschung [en ligne] URL: https://nbn-resolving.org/urn:nbn:de:0168-ssoar-259138

Prost Antoine (1992) L'enseignement s'est-il démocratisé ? Les élèves des lycées et collèges de l'agglomération d'Orléans de 1945 à 1990, Paris, Presses universitaires de France, 227 p.

Reitz Jeffrey G. (2001), Immigrant success in the economy knowledge economy: institutional change and the immigrant experience in Canada, 1970-1995, Journal of Social Issues, 57 (3), pp. 579-613.

Rothon Catherine, Heat Antony and Lessard-Philips Laurence (2009) The educational attainments of the "second generation": A Comparative study of Britain, Canada, and the United States, Teachers College Record, 111 (6), pp. 1404-1443.

Schneeweis Nicole (2013) Immigrant concentration in schools: Consequences for native and migrant students, Discussion paper 7230, Bonn, University of Linz, NRN Labor \& Welfare State and IZA, $42 \mathrm{p}$.

Schnell Philipp and Azzolini Davide (2015) The academic achievements of immigrant youths in new destination countries: Evidence from southern Europe. Migration studies, Migration Studies, 3 (2), pp. 217-240.

Schnepf Sylke (2007) Immigrants' educational disadvantage: an examination across ten countries and three surveys, Journal of Population Economics, 20 (3), pp. 527-545.

Shakya Yogendra B., Guruge Sepali, Hynie Michaela, Akbari Arzo, Malik Mohamed, Htoo Sheila, Azza Khogali, Mona Stella Abiyo, Murtaza Rabea and Alley Sarah (2010) Aspirations for higher education among newcomer refugee youth in Toronto: Expectations, challenges, and strategies, Refugee, 27 (2), pp. 65-78.

Simich Laura, Beiser Morton, Stewart Miriam and Mwakarimba Edward (2005) Providing social support for immigration and refugees in Canada: Challenges and directions, Journal of Immigrant Health, 7 (4), pp. 259-268.

Söhn Janina and Özcan Veysel (2006) The Educational Attainment of Turkish, Turish Studies, 7 (1), pp. 101-124.

Statistique Canada (2017) Profil du recensement, Recensement de 2016, Statistique Canada, Ottawa, Statistique Canada, [en ligne]. URL: http://www12.statcan.gc.ca/census-recensement/2016/dp$\mathrm{pd} / \mathrm{prof} /$ index.cfm?Lang=F

Statistique Canada (2017 Recensement de la population en 2016: immigration et diversité ethnoculturelle, Ottawa, Statistique Canada, [en ligne]. https://www12.statcan.gc.ca/census-recensement/2016/ ref/98-501/98-501-x2016008-fra.pdf

Thiessen Victor (2009) The pursuit of postsecondary education: A comparison of First Nations, African, Asian, and European Canadian Youth, Canadian Review of Sociology, 46 (1), pp. 5-37. 
Zlotnik Honia (1995) The South-to-North Migration of Women, International Migration Review, 29, pp. 229-254.

Zlotnik Honia (1991) Trends in South to North Migration: The Perspective from the North, International Migration, 29 (2), pp. 317-331.

\section{NOTES}

1. According to Statistics Canada (2017), the term "immigrant" refers to any person who is, or was, a landed immigrant or permanent resident. This is any person who has been granted permanent residence by immigration authorities. Immigrants who became Canadian citizens by naturalization are included in this category.

\section{ABSTRACTS}

This article aims to describe and understand the postsecondary pathway morphologies of immigrant youth in Quebec, as well as the factors contributing to structuring them. The results obtained from the analysis of the Ministry of Education data $(\mathrm{N}=20,387)$ show that these young people pursue postsecondary education through linear pathways in larger proportions than their peers whose parents are born in Canada. However, the differences are much higher at university level than at that of general and vocational colleges (known by their French acronym CÉGEP: Collège d'enseignement général et professionnel). In addition, there are significant differences among immigrant youth according to the geographical region of origin of their parents. In contrast, there is almost no difference in nonlinear pathways. This article suggests some possible interpretations.

Cet article vise à décrire et comprendre la morphologie des parcours des jeunes Québécois issus des familles immigrantes dans l'enseignement supérieur, ainsi que les facteurs qui contribuent à la structuration de ces parcours. Les résultats obtenus à partir des données du ministère de l'Éducation $(\mathrm{N}=20,387)$ révèlent que ces jeunes poursuivent les études supérieures par la voie des parcours linéaires dans une proportion plus élevée que leurs pairs dont les parents sont nés au Canada. Toutefois, les différences sont nettement plus élevées à l'université qu'au collège d'enseignement général et professionnel (CEGEP). De plus, il existe des différences significatives parmi les jeunes d'origine immigrante selon l'origine géographique des parents. En revanche, il n'y a presque pas de différence à propos des parcours non linéaires. L'article suggère quelques pistes d'interprétation.

Este artículo tiene por objeto la descripción y comprensión de la morfología de trayectorias de jóvenes de origen inmigrante en la educación superior, así que los factores que contribuyen a su estructuración. Los resultados recogidos a partir de datos del ministerio de Educación $(\mathrm{N}=20,387)$ demuestran que estos jóvenes cursan estudios superiores siguiendo trayectorias lineales en mayor proporción que sus pares cuyos padres nacieron en Canadá. Sin embargo, las diferencias son considerablemente más altas en la universidad que en los colegios de enseñanza general y profesional (CEGEP en Quebec). Además, se observan diferencias significativas entre los jóvenes de origen inmigrante según el origen geográfico de los padres. En cambio, no se observan 
diferencias en lo que concierne las trayectorias no lineales. Este artículo propone pistas de interpretación de dichos resultados.

\section{INDEX}

Keywords: higher education, postsecondary pathways, program choice, immigrant students

Palabras claves: educación superior, trayectorias escolares, elección de programas, inmigrantes Mots-clés: études supérieures, parcours scolaire, choix de programmes, immigrants

\section{AUTHORS}

\section{PIERRE-CANISIUS KAMANZI}

Associate professor at the department of administration and foundations of education, University of Montreal, Pavillon Marie-Victorin, local A-511, C.P. 6128, succursale Centre-ville, Montréal, Canada H3C 3J7 ; pierre.canisius.kamanzi@umontreal.ca

\section{MARIE-ODILE MAGNAN}

Associate professor at the department of administration and foundations of education, University of Montreal, Pavillon Marie-Victorin, local A-511, C.P. 6128, succursale Centre-ville, Montréal, Canada H3C 3J7 ; marie-odile.magnan@umontreal.ca

\section{ANNIE PILOTE}

Professor at the faculty of education science at the Laval university, Pavillon des sciences de l'éducation, 2320 rue des Bibliothèque, Québec, Canada G1V 0A6; annie.pilote@fse.ulaval.ca

\section{PIERRE DORAY}

Professor at the department of sociology, University of Montreal, CP 8888, succursale Centreville, Québec, Canada H3C3P8 ; doray.pierre@uqam.ca 